\section{Sciendo}

WOJCIECH POKOJSKI

University of Warsaw

Faculty of Geography and Regional Studies

Chair of Geomatics and Information Systems

Warsaw, Poland

orcid.org/0000-0003-3473-3512

wpokojski@uw.edu.pl

PAULINA POKOJSKA

University of Warsaw

Faculty of Geography and Regional Studies

Warsaw, Poland

orcid.org/0000-0002-9729-0547

ppokojska@uw.edu.pl
Polish Cartographical Review

Vol. 50, 2018, no. 3, pp. 141-150

DOI: $10.2478 /$ pcr-2018-0009

Received: 25 Juni 2018

Accepted: 31 October 2018

\title{
Voronoi diagrams - inventor, method, applications
}

\begin{abstract}
The article presents the person and works of Georgy Voronoi (1868-1908), the inventor of an original method of diagrams, a student of the famous mathematician Andrey Markov. Georgy Voronoi graduated from the Department of Physics and Mathematics at the University of St. Petersburg, and subsequently worked as a professor of mathematics at the Imperial University of Warsaw. One of his students was the future outstanding Polish mathematician Wacław Sierpiński. In his brief lifetime G. Voronoi published several important scientific articles on number theory. In an almost 100 page paper in French published in 1908 he described a method of diagrams, or polygons, which became known as the method of Voronoi diagrams.

In the digital age this method and its modifications found new applications. The entry "Voronoi" is getting more popular on the Internet, and the method of Voronoi diagrams and its modifications are widely described in handbooks and scientific articles. The article presents application of the method in the most popular computer programs from the Geographic Information System (GIS) group and presents examples of its usage in research on geographic space in various scientific disciplines.
\end{abstract}

Keywords: Voronoi diagram, Georgij Voronoi, GIS, University of Warsaw

\section{Introduction}

Voronoi diagrams are a method of spatial data interpolation into polygons around each point in such a way, that each location from the area surrounding a given point is closer to it than to any other point. This method, which was invented over 100 years ago by a University of Warsaw professor, and which has been used in many disciplines of science all over the world, finds new applications in the digital age. The article presents the person of Georgy Voronoi (1868-1908), collects GIS software which uses his method and provides examples of applying Voronoi diagrams in various disciplines of science. The 150th birth anniversary is a good occasion to learn more about the out- standing scientist, popularity of his method in GIS applications and its various uses in scientific research.

\section{Georgy Voronoi}

\subsection{Childhood and youth in Ukraine}

Georgy Voronoi was born on 16 April 1868 in the town of Zhuravka, in the former Poltava Governorate. He came from a Ukrainian family, but used the Russian form Voronoi of his family name rather than the Ukrainian Voronyi ( $\mathrm{H}$. Syta 2010, A. Schinzel 2016). His father, Theodozij Voronoi (1837-1910) was a Russian philologist, secondary school teacher, initiator and 
founder of several school, including a school for working adults (H. Syta 2001).

Georgy graduated from a 5-year elementary school in Berdiansk, and a gymnasium in Priluki.

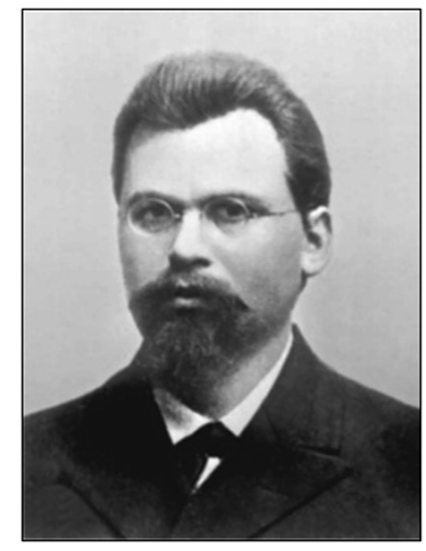

Fig. 1. Georgy Voronoi (1868-1908)

His math teacher, Ivan Bogoslovski, who encouraged him to publish, was a major influence on Voronoi's interest in science. At the age of 17 , while still in gymnasium, Voronoi published a scientific article on decomposition of polynomials in „Zhurnal Elementarnoj Matematiki”, one of the mathematic magazines published at University of Kiev (H. Syta 2010, A. Schinzel 2016).

\subsection{Studies in St. Petersburg}

In 1885, just after graduating from gymnasium, G. Voronoi took up studies at the Department of Physics and Mathematics at the University of St. Petersburg. His main area of interest was number theory; still a student he wrote a paper on Bernoulli numbers which he presented in 1889 as his candidate's thesis. His scientific tutor was the famous mathematician Andrei Markov (A. Schinzel 2016), the inventor of the method of research of dependent events known now as Markov chain. This research marked the beginning of development of modern theory of probability - the theory of Markov stochastic processes. After receiving the title of a candidate and having completed his studies, G. Voronoi became a math teacher at the progymnasium in Peterhof (A. Schinzel 2016); in parallel he was preparing his Master's thesis (Russian equivalent of a doctoral thesis) on integers, which he completed in 1894 (MacTutor History of Mathematics).

\subsection{Work at the University of Warsaw}

In 1894, after receiving his Master's degree, at the age of 26 Voronoi was sent to work at the Imperial University of Warsaw. At first employed as a docent and then as an associate professor (R. Duda 2016), he lectured in analytic geometry, differential calculus and integral calculus, as well as prepared handbooks for these subjects (A. Schinzel 2016). In parallel he conducted intensive scientific research and worked on his doctoral thesis which he defended in St. Petersburg in 1897. In 1898 he was elected a member of the Moscow Mathematical Society and in 1898 and 1901 he participated in congresses of Russian biologists and physicians. In 1904 he presented two papers at the international congress of mathematics in Heidelberg. In recognition of his scientific activity he became a corresponding member of the St. Petersburg Academy of Sciences.

G. Voronoi had large contribution into the development of the Polish school of mathematics. One of his students at the University of Warsaw was a famous Polish mathematician Wacław Sierpiński. Voronoi commissioned him to solve a problem in the area of number theory. Sierpiński received a medal for excellent solution of the problem, and later developed the same topic in his candidate's thesis (J. Hurwic 2016). First works of W. Sierpiński, including his doctoral and postdoctoral theses, were also written under strong influence of Voronoi (A. Schinzel 2016).

It should be noted that the Imperial University of Warsaw at that time was for the Russian Empire a provincial school, with no particular research objectives. Using the Polish language was forbidden and the school showed clear tendency towards Russification (R. Duda 2016). Within the University there was i.a. the Department of Physics and Mathematics with 11 chairs, among them the Chair of Mathematics led by Voronoi (H. Syta 2010). Voronoi refrained from politics, just like other scientists from his department. According to J. Schiller-Walicka (2016) some of the Russian professors, especially 
from the medical and mathematical-physical departments attempted to perform their duties accordingly, and many professors preferred not to take any political stance. Additionally, professors employed by the University sought additional teaching jobs. Voronoi, for example, in 1898 took the chair of mathematics at the Polytechnic Institute of Emperor Nicholas II (the activity of which is continued by the Warsaw University of Technology) (J. Miąso 1989, A. Ulmer 2016).

After the revolution of 1905 in the Kingdom of Poland, the Russian authority planned to move the University of Warsaw into one of Russian cities. G. Voronoi negotiated for Voronezh (J. Schiller 2005), but finally for the years 1906-1907 the university was moved to Novocherkassk. During a one year stay in Novocherkassk Voronoi acted as the dean of the Mechanical Department. Unfortunately, unfavorable living conditions in the city resulted in serious deterioration of his health (J. Schiller-Walicka 2016).

In the fall of 1908 classes at the University of Warsaw were resumed and Voronoi returned to Warsaw. Soon after that he died at the age of 40 and was buried in his a family village of Zhuravka in Ukraine (H. Syta 2010). Wacław Sierpiński bid farewell to his professor with a lecture at the University of Lvov. He stated that "all the works of Voronoi are distinguished with utmost accuracy from the scientific point of view, and with exceptional clarity and simplicity of discourse from the didactic one. He was a person never short of topics for scientific research. It is a well known fact that in mathematics it is perhaps most difficult to find for oneself a topic both appropriate and productive... All his works are truly original and prove his outstanding talent..." (W. Sierpiński 1908).

\section{Voronoi diagrams}

\subsection{Scientific papers}

During his brief lifetime G. Voronoi managed to start several new directions in modern number theory. He wrote 12 scientific papers, 8 of which are scientifically relevant also today ${ }^{1}$.

\footnotetext{
${ }^{1}$ http://mir-prekrasen.net/referat/4254-georgiy-feodosevich.html
}

Voronoi published his discoveries on polygons and number theory in 1907 in the paper titled Properties of positive, perfect quadratic forms ${ }^{2}$.

The first idea of applying spatial division in a way resembling Voronoi diagrams known in literature was the method describing distribution of matter in the universe mentioned by Descartes in 1644 (R. Descartes 1644). Later that method was presented by G.L. Dirichlet (1850) and after him it was named Dirichlet tessellation (A. Okabe et al. 2009).

G. Voronoi proposed a development of that method in an almost one hundred page paper Nouvelles applications des paramètres continus à la théorie de formes quadratiques published in „Journal für die Reine und Angewandte Mathematik" (G. Voronoi 1908), the oldest mathematical journal still published. He signed it Georges Voronoi a Varsovie; he quoted i.a. works of Dirichlet, whose method he developed. A hundred years since its publication in print the article was published online in www.degruyter. com $^{3}$ repository.

\subsection{Thiessen or Voronoi polygons?}

In the article Precipitation averages for large areas published in 1911, the American meteorologist Alfred H. Thiessen (1872-1931) proposed a method of delimitation of polygons of precipitation areas (A. Thiessen 1911, A.H. Schumann 1998) which made it possible to delimit polygons identical to those obtained with the method of Voronoi diagrams. The method of Thiessen polygons found its use in meteorology to elaborate the precipitation area on the basis of measured values as the so-called method of polygons of equal precipitation (P.Z. Sen 2009).

The method of designing Thiessen/Voronoi diagrams described in encyclopedias, handbooks and tutorials is referred to as Voronoi diagrams or polygons (fig. 2), and sometimes as Thiessen polygons. According to a discussion on a popular forum devoted to GIS, both scientists worked on the same idea and method independently, therefore it should bear a double

\footnotetext{
2 https://slovar.wikireading.ru/2408143, https://dic.academic.ru/dic.nsf/ruwiki/140128

${ }^{3}$ https://www.degruyter.com/view/j/crll.1909.issue-136/ crll.1909.136.67/crll.1909.136.67.xml
} 


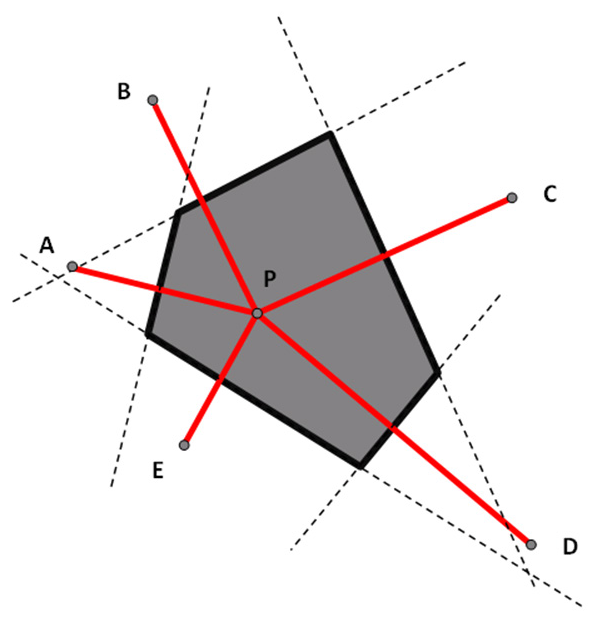

Fig. 2. Graphic representation of Voronoi polygons (own elaboration)

name ${ }^{4}$. The most popular GIS package distributed as Open Source QGIS uses the name Voronoi polygon.

It is worth mentioning that the problem of building reference fields around points was analyzed by Lech Ratajski, who introduced the concept of variable-dense network to cartographic literature (J. Szewczuk 1977).

\subsection{Popularity of the entry Voronoi on the Internet}

The method of Voronoi diagrams is becoming more popular and its significance can be seen in the query conducted online (10 April 2018). After entering "voronoi" or "voronoi diagram" into Google search engine we received respectively over 2 million and 1 million hits, on youtube. com channel we got access to over 6 thousand films; some of which have over 100 thousand views. On the scientific site Researchgate we get a set of about 100 articles with the word Voronoi in the title placed on the site since the beginning of 2017 (last 18 months). Another proof of the popularity of the method is Wikipedia, where Voronoi diagrams are described in no less than 25 languages ${ }^{5}$.

\footnotetext{
${ }^{4}$ https://gis.meta.stackexchange.com/questions/3677/ voronoi-vs-thiessen-vs-delaunay-triangulation-one-or-moretags).

${ }^{5}$ https://pl.wikipedia.org/wiki/Diagram_Woronoja
}

\subsection{Popularity of the method in scientific handbooks}

The entry Voronoi did not appear in encyclopedias published in the 1980s and 1990s, such as the Polish edition of Brittanica, Larousse's encyclopedia or the „Wielka Encyklopedia PWN" (Great Encyclopedia of Polish Scientific Publishers). It was only the development of computer calculation methods, computer graphic design, molecular biology and, most importantly, software of Geographic Information Systems (GIS) that amplified the significance of calculation of Voronoi diagrams in many disciplines: computational geometry, engineering, mathematics, geography, geoinformatics.

One of the first book publications fully devoted to the Voronoi method dates from 2000 (A. Okabe et al. 2009). In the following years there appeared several important publications on Voronoi diagrams, i.a. Voronoi diagram: A geometry-based approach to computational intelligence published by Springer in 2008, which aimed to "perform a profound review and analysis of basic methods and techniques elaborated according to Voronoi's concepts" (M. Gavrilova 2008) and Voronoi diagrams and Delaunay triangulations published by World Scientific Publishing in 2013 (F. Aurenhammer et al. 2013). Explanations of Voronoi diagrams were also prepared for student handbooks and various training materials (M. Serwecińska 2014).

In Geographic Information Systems and science (P.A. Longley et al. 2005) handbook the authors use the name Thiessen polygons, mentioning that the method is also known as Voronoi and Dirichlet polygons. A special note devoted to the scientist Atsu Okabe reads that he is a specialist in "designating Thiessen polygons using Voronoi diagrams".

Polish authors of handbooks in geoinformatics (GIS), when referring to the method of polygons, interchangeably use two names Thiessen and Voronoi. Thiessen polygons appear in the first Polish handbook of geoinformatics by J. Gaździcki (1990). In some later publications authors give both names together. A. Magnuszewski (1999) uses the term "Thiessen polygons, also known as Voronoi polygons or Dirichlet tessalation", J. Urbański (2008) writes about Thiessen polygons, but also men- 
tions interchangeable names - Dirichlet or Voronoi diagrams.

Cyclical international symposia devoted to Voronoi diagrams are another proof of the method's significance (International symposium on Voronoi diagrams in science and engineering $)^{6}$. The conference organized on the 145 anniversary of Voronoi's birth in Kiev in 2013 included papers referring to his scientific heritage in six research areas ${ }^{7}$.

\section{Popularity of the method in GIS application and its significance in scientific research}

Most popular examples and applications of Voronoi diagrams (Thiessen polygons) as a GIS software tool are presented below.

\subsection{Implementation of Voronoi diagrams in GIS applications}

Not many methods and algorithms programmed in GIS are named after their inventors. The method of Voronoi diagrams (Thiessen polygons) is an exception here.

On the list of computational modules of GRASS GIS there is only one module with a name, and it is Voronoi (v.voronoi - Creates a Voronoi diagram constrained to the extents of the current region from an input vector map containing points or centroids) $)^{8}$.

In computer programs from GIS group which were created in the United States the above method was described using the name of Thiessen (ArcGIS) or Voronoi (GRASS GIS, Maplnfo). Older versions of ArcGIS program (e.g. 9.2) still used the term Voronoi maps ${ }^{9}$. In programs distributed with free license the name Voronoi is used more often (ILWIS, GRASS GIS, QGIS) than Thiessen, (e.g. in SAGA). Table 1 presents a selection of GIS programs, and shows placement of tools in program menus or tool boxes.

\subsection{Application of Voronoi diagrams}

Below follows a list of example applications of Voronoi diagrams, both in the classic form of two-dimensional polygons and with modifications. The method of Voronoi diagrams (often under the name of Thiessen polygons) is used to construct maps of representativeness of points (fig. 3), e.g. such as the method of precipitation areas mentioned earlier.

Voronoi diagrams are also used in the research of socio-economic phenomena. Polygons in their classic form were used to determine transportation accessibility of, i.a. railway stations and other transportation stops, schools, hospitals (H. Wu et al. 2013, F. Karimi et al. 2009, F. Rezende et al. 2000).

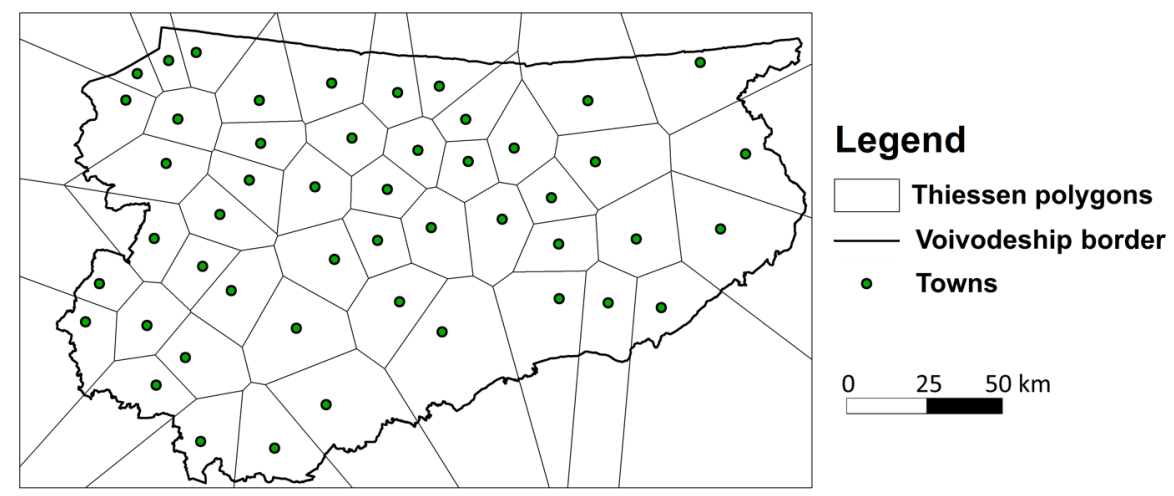

Fig. 3. Thiessen/Voronoi polygons for towns in Warmia-Mazury Voivodship (own elaboration)

\footnotetext{
${ }^{6}$ http://voronoi.hanyang.ac.kr/vd2005/ http://bioinf.spbau. ru/isvd2013/home

${ }^{7}$ http://www.fmi.npu.edu.ua/ua/voronoi2013
}

\footnotetext{
${ }^{8}$ GRASS GIS manual - https://grass.osgeo.org/grass75/ manuals/v.voronoi.html

${ }^{9} \mathrm{http}: / /$ webhelp.esri.com/arcgisdesktop/9.2/index. cfm?TopicName=Voronoi_maps
} 
Table 1. Modules to calculate Voronoi (Thiessen) polygons in the most popular GIS programs; the program, location in the program menu, graphic presentation of the tool window

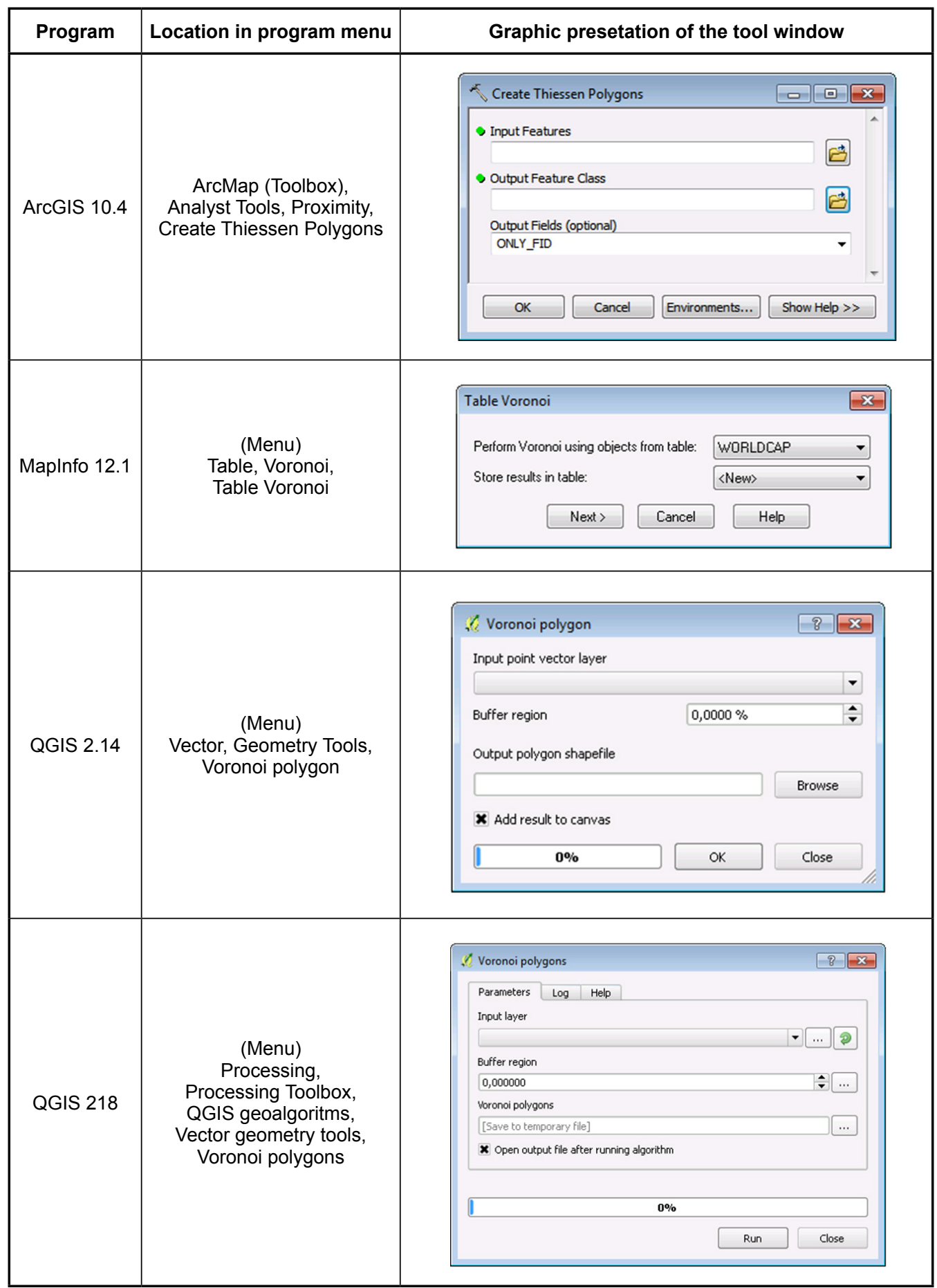




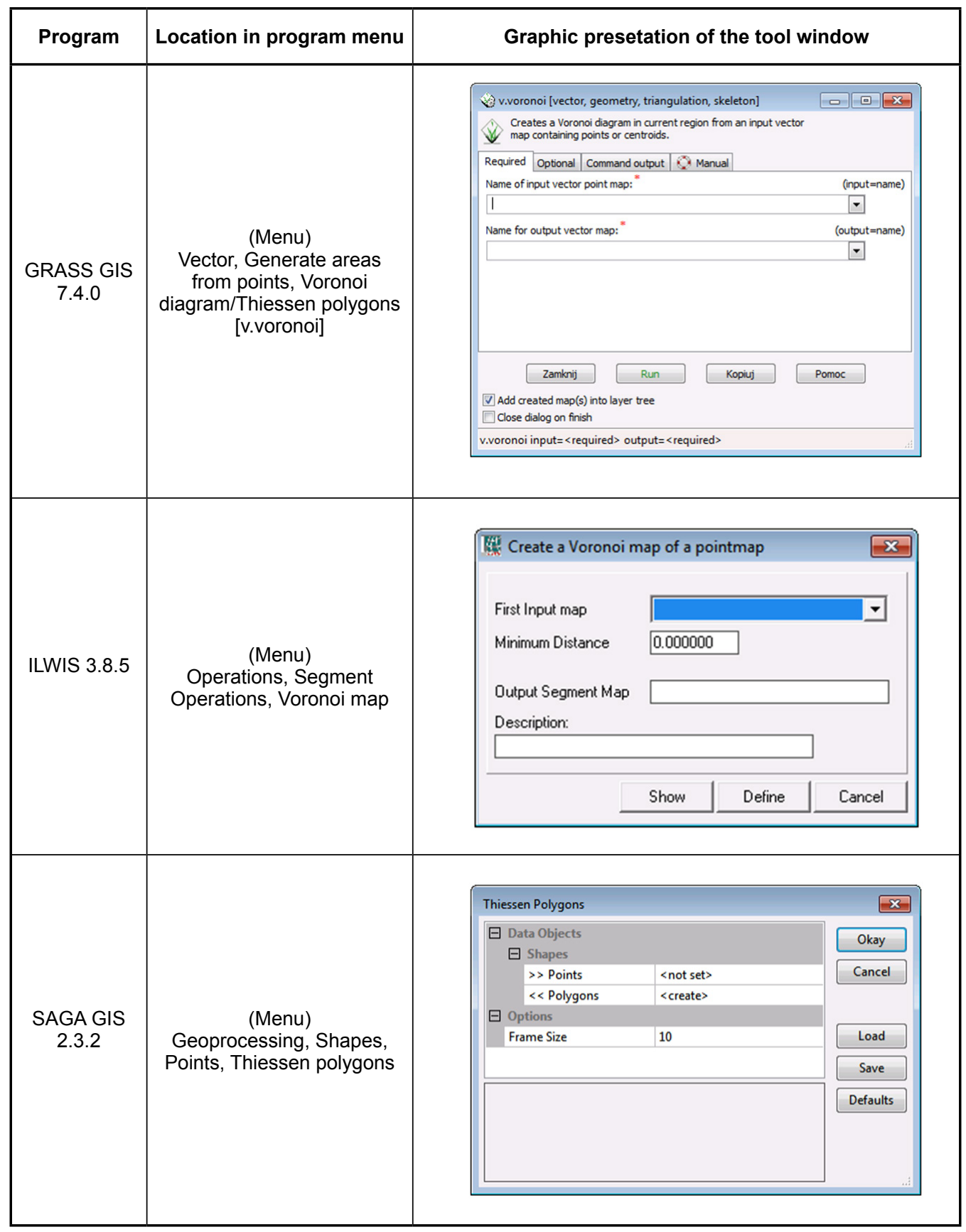


The polygon method was used to analyze spatial patterns of distribution and accessibility of discount stores (W. Kisiała, M. Rudkiewicz 2017), to determine accessibility of green areas in certain large cities in Europe (A. Bochenek, T. Jasiński 2015) and to determine relation between community and the closest service provider (S. Lovacka 2008). The most popular examples of the method's application are delimitation of school zones and availability of medical services in the area of Presov in Slovakia (S. Lovacka, 2008) and elaboration of ranges of landscape in cultural borderland (A. Awramiuk-Godun 2013). In research conducted on the Beijing agglomeration, Voronoi (Thiessen) polygons were used to determine the zone of transit transportation (S. Wang et al. 2014). Voronoi polygons were also used for delimitation of maritime zones, e.g. in the Gulf of Salwa between Saudi Arabia and Qatar (G. Cosquer, J.F. Hangouët 2003).

The so-called weighted Voronoi diagram method is a modification of Voronoi diagrams. It consists in increasing or decreasing the ranges of diagrams around a point depending on the weight given to such a point (F. Aurenhammer, H. Edelsbrunner 1984; A. Okabe et al. 2009; P. Dong 2008). The method in such form was used to obtain algorithm for calculation of convex distances in transportation networks (W. Bae, K.Y. Chwa 2005).

\subsection{Computer graphic design}

Development of computer graphic design makes it possible to construct Voronoi diagrams in 3D version using computer animations (H. Ledoux 2007), e.g. to describe crystal structure and the structure of atoms in a three-dimensional form (Y. Xu et al. 2013), or for

\section{Literature}

Anton F., Gold C.M., Mioc D., 1998, Local coordinates and interpolation in a Voronoi diagram for a set of points and line segments. In: The Voronoi Conference on Analytic Number Theory and Space Tillings, pp. 9-12.

Aurenhammer F., Edelsbrunner H., 1984, An optimal algorithm for constructing the weighted Voronoi diagram in the plane. "Pattern Recognition" Vol. 17 no. 2, pp. 251-257. https://doi.org/10.1016/00313203(84)90064-5 planning paths for Unmanned Underwater Vehicles (UUVs) (M. Candeloro et al. 2017). T. van der Putte (2009) extensively presented possible usage of Voronoi diagrams in 3D modeling. The number of possible applications of diagrams in 3D version will probably increase as a result of placing a computational module in the popular computational environment MATLAB (Mathworks Documentation).

\section{Summary}

The year 2018 marks the 100th anniversary of the foundation of the Chair of Geography at the University of Warsaw. However, several years earlier Georgy Voronoi, a professor of the Imperial University of Warsaw, invented an algorithm which is known and used all over the world. Voronoi diagram method finds application in delimitation of space in sciences related to geographical space.

Development of GIS software undoubtedly helped the popularity of the method. Regretfully, in the ArcGIS program the module calculating Voronoi diagrams is called Thiessen polygons. As a result many users all over the world employ methods invented by the two scientists, but are not familiar with the name Voronoi. And Voronoi is the only name connected to Poland appearing in the menu (tools) of GIS software.

In conclusion let us quote M.I. Kratko (2011), vice-rector of the University of Luck (Ukraine): "In the person of Georgy Voronoi we have an example of an honest labor of a Ukrainian scientist within the realm of Polish science which later influenced the development of science in Ukraine, and especially at the University of Lvov, where Voronoi's students and their subsequent disciples founded the famous Lvov school of mathematics".

Aurenhammer F., Klein R., Lee D.-T., 2013, Voronoi diagrams and Delaunay triangulations. Singapore: World Scientific Publishing.

Awramiuk-Godun A., 2013, Rozmieszczenie obiektów sakralnych jako kryterium wyznaczania zasięgu krajobrazu pogranicza kulturowego. „Prace Komisji Krajobrazu Kulturowego” Nr 19, pp. 62-72.

Bae W., Chwa K.Y., 2005, Shortest paths and Voronoi diagrams with transportation networks under general distances. Berlin, Heidelberg: Springer Verlag. 
Biografia Markow. (http://wazniak.mimuw.edu.pl/index.php?title=Biografia_Markow\%2C_Andriej

Bochenek A., Jasiński T., 2015, Zastosowanie algorytmu Woronoja do określenia dostępności terenów zieleni w wybranych, dużych miastach Europy. „Współczesne problemy i kierunki badawcze w geografii" T. 3, Instytut Geografii i Gospodarki Przestrzennej UJ, pp. 17-27.

Candeloro M., Lekkas A.M., Sorensen A.J., 2017, A Voronoi-diagram-based dynamic path-planning system for underactuated marine vessels. "Control Eng. Pract." Vol. 61, pp. 41-54. DOI: 10.1016/j. conengprac.2017.01.007

Cosquer G., Hangouët J.F., 2003, Delimitation of land and sea boundaries: Geodetic and geometric bases. FIG Working Week 2003, Paris, France, April 13-17. https://www.fig.net/resources/proceedings/fig_proceedings/fig_2003/TS_20/PP20 1_Cosquer_Hangouet.pdf

Dakowicz M., Gold C., 2002, Extracting meaningful slopes from terrain contours. In: Computational Science - ICCS 2002. Eds. S.P.M.A. Sloot, A.G. Hoekstra, C.J.K. Tan, J.J. Dongarra, "Lecture Notes in Computer Science" Vol. 2331. Berlin, Heidelberg: Springer.

Descartes R., 1644, Le monde de M. Descartes ou le Traité de la Lumière. Paris.

Dirichlet G.L., 1850, Über die Reduction der positieven quadratischen Formen mit drei unbestimmten ganzen Zahlen. „Journal für die Reine und Angewandte Mathematik" Vol. 40, pp. 209-227.

Dong P., 2008, Generating and updating multiplicatively weighted Voronoi diagrams for point, line and polygon features in GIS. "Computers \& Geosciences" Vol. 34, no. 4, pp. 411-421.

Duda R., 2016, Matematyka. Nauki ścisłe i przyrodnicze na Uniwersytecie Warszawskimm. In: Dzieje Uniwersytetu Warszawskiego 1816-1915. Ed. T. Kizwalter, "Monumenta Universitatis Varsoviensis 1816-2016", Warszawa: Wydawnictwa Uniwersytetu Warszawskiego.

Gavrilova M., Ed. 2008, A Geometry-based approach to computational intelligence. "Studies in Computational Intelligence" 158 . Springer.

Gaździcki J., 1990, Systemy informacji przestrzennej. Warszawa: Państwowe Przedsiębiorstwo Wydawnictw Kartograficznych.

Georgij Woronoj. https://ru.wikipedia.org/wiki

Hurwic J., 2016, Wacław Sierpinski 1882-1969. In: Dzieje Uniwersytetu Warszawskiego 1816-1915. Ed. T. Kizwalter, „Monumenta Universitatis Varsoviensis 1816-2016", Warszawa: Wydawnictwa Uniwersytetu Warszawskiego, p. 231.

Karimi F., Delavar M.R., Mostafavi M.A., 2009, Space allocation of educational centers using multiplicatively weighted Voronoi diagram. ISPRS COST Workshop on Quality Scale and Analysis Aspects of City Models, Lund.
Kisiała W., Rudkiewicz M., 2017, Zastosowanie diagramu Woronoja w badaniu przestrzennych wzorców rozmieszczenia i dostępności sklepów dyskontowych. „Przegląd Geograficzny” T. 89, nr 2, pp. 187-212.

Kratko M.I., 2011, Heorhij Woronyj - matematyk ukraiński i polski. http://voronuy.at.ua/publ/heorhij_ woronyj_matematyk_ukrainski_i_polski/1-1-0-48

Ledoux H., 2007, Computing the 3D Voronoi diagram robustly: An easy explanation Voronoi diagrams in science and engineering. 2007. ISVD '07. 4th International Symposium, pp. 117-129.

Longley P.A., Goodchild M., Maguire D.J., Rhind D.W., 2005, Geographic Information Systems and Science. Chichester - New York: John Wiley \& Sons, 342 pp.

Lovacka S., 2008, The use of the Voronoi tessellation for purposes of service distribution districts delimitation (The example of the Prešov nodal region). „Folia Geographica” Vol. 12, pp. 163-171.

MacTutor History of Mathematics. http://www-groups. dcs.st-and.ac.uk/ history/Biographies/Voronoy.html

Magnuszewski A., 1999, GIS w geografii fizycznej. Warszawa: Wydawnictwo Naukowe PWN.

Mathworks Documentation. Woronoi diagrams. https:// www.mathworks.com/help/matlab/math/voronoi-diagrams.html

Miąso J., 1989, Trudne narodziny Politechniki Warszawskiej: (przyczynek do dziejów polityki naukowej w Królestwie Polskim). „Kwartalnik Historii Nauki i Techniki" T. 34, nr 4, pp. 777-818.

Okabe A., Boots B., Sugihara K., Chiu S.N., 2009, Spatial tessellations: Concepts and applications of Voronoi diagrams. Chichester - New York: John Wiley \& Sons.

Rezende, F., Almeida R., and Nobre, F., 2000, Diagramas de Voronoi para a definicao de areas de abrangencia de hospitais publicos no Municipio do Rio de Janeiro. „Cadernos de Saude Publica” T. 16 , no. 2, pp. 467-475.

Schiller J. 2005, Uniwersytet Warszawski. Czy Uniwersytet i czy w Warszawie? „Kwartalnik Historii Nauki i Techniki" T. 50, nr 2-4, pp. 25-58.

Schiller-Walicka J., 2016, Cesarski Uniwersytet Warszawski: między edukacją a polityką 1869-1917. In: Dzieje Uniwersytetu Warszawskiego 1816-1915. Ed. T. Kizwalter, „Monumenta Universitatis Varsoviensis", Warszawa: Wydawnictwa Uniwersytetu Warszawskiego, pp. 557-703.

Schinzel A., 2016, Georgij Woronoj - Mistrz Wacława Sierpińskiego. In: Portrety uczonych. Profesorowie Uniwersytetu Warszawskiego 1816-1915. Eds. M. Wąsowicz, A.K. Wróblewski. Warszawa: Wydawnictwa Uniwersytetu Warszawskiego, p. 491.

Schumann A.H., 1998, Thiessen polygon. In: Encyclopedia of Hydrology and Lakes, "Encyclopedia of Earth Science". Dordrecht: Springer, pp. 648-649.

Sen P.Z., 2009, Spatial modeling principles in earth sciences. Springer, pp. 52-54. 
Serwecińska M., 2014, Diagramy Voronoi. Letnia Szkoła Matematyki. Uniwersytet Śląski. http://www.math. us.edu.pl/Isim2014/MSerwecinska-lsim2014.pdf

Sierpiński W., 1908, Georgij Woronoj. Streszczenie wykładu, wypowiedzianego na Uniwersytecie Lwowskim dnia 23 listopada 1908 r. In: Portrety uczonych. Profesorowie Uniwersytetu Warszawskiego 1816-1915. Eds. M. Wąsowicz, A.K. Wróblewski. Warszawa: Wydawnictwa Uniwersytetu Warszawskiego, pp. 484-490.

Syta H. 2010, Short biography of G. Voronoi. http:// voronuy.at.ua/publ/statti_anglijska_mova/short_ biography_of_g_voronoi_p1/4-1-0-49

Syta H. 2001, The scientific legacy of Georgii Voronoi and contemporary science. In: Mathematics and the mathematical sciences in Ukraine in the twentieth century (Natsional. Akad. Nauk Ukrainy Inst. Mat., Kiev - 2001), pp. 89-94.

Szewczuk J., 1977. Sieć zmienogęsta nieregularna, „Polski Przegląd Kartograficzny” Vol. 9, no. 1, pp. 1-12.

Thiessen A., 1911, Precipitation averages for large areas. "Monthly Weather Review" Vol. 39, no. 7, pp. 1082-1089.

Ulmer A., 2016, Dzieje Politechniki Warszawskiej w zarysie. „Maszyny Elektryczne - Zeszyty Problemowe" Vol. 4(112), pp. 193-199.
Urbański J., 2008, GIS w badaniach przyrodniczych. Gdańsk: Wydawnictwo Uniwersytetu Gdańskiego, p. 53.

van der Putte T., 2009, Using the discrete 3D Voronoi diagram for the modelling of $3 D$ continuous information in geosciences. Master Thesis, Geographical Information Management and Applications. Utrecht University in Geographical Information Management and Applications. http://www.gdmc. nl/publications/2009/3D_Voronoi_diagram.pdf

Voronoi G., 1908, Nouvelles applications des paramètres continus à la théorie de formes quadratiques. „Journal für die Reine und Angewandte Mathematik" Vol. 134, pp. 198-287.

Wang S., Rong J., Yang Z., 2014, Transit traffic analysis zone delineating method based on Thiessen polygon. "Sustainability" Vol. 6, no. 4, pp. 1821-1832. DOI: 10.3390/su6041821

Wu H., Takahashi S., Lin C., Yen H., 2013, Voronoi-based label placement for metro maps. In: 17th International Conference on Information Visualization. London 2013, pp. 96-101. DOI: 10.1109/IV.2013.11

Xu Y., Fan X.H., Liu K.G., Shi L., Xu. B., Wang F.M., Lin J.P., 2013, Applying and practicing of MATLAB programing for Voronoi tessellation. "Advanced Materials Research” Vol. 706-708, pp. 391-394. 